\title{
ECOLOGIA, NOVA ERA E PEREGRINAÇÃO: UMA ETNOGRAFIA DA EXPERIÊNCIA DE CAMINHADAS NA ASSOCIAÇÃO DOS AMIGOS DO CAMINHO DE SANTIAGO DE COMPOSTELA DO RIO GRANDE DO SUL
}

\author{
Rodrigo Toniol ${ }^{1}$ \\ Carlos Alberto Steil
}

Resumo: Este trabalho é uma etnografia sobre a experiência de caminhadas na Associaçáo dos Amigos do Caminho de Santiago do Rio Grande do Sul (ACASARGS). Procuramos, aqui, compreender como na prática dos caminhantes podem estar sobrepostos sentidos relacionados aos hábitos ecológicos e religiosos. Para tanto, privilegiam-se, na narrativa etnográfica, as motivaçóes, os interesses e as experiências dos caminhantes, buscando apreender os múltiplos sentidos atribuídos ao caminhar, que abrigam significados distintos e mesmo contraditórios. A construção teórico-metodológica desta análise sedimenta-se na proposta do paradigma da corporeidade de Thomas Csordas que pretende, sobretudo, traduzir a fenomenologia para o campo antropológico e assim colapsar dicotomias como mente/corpo, natureza/cultura e sujeito/objeto.

Palavras-chave: Ecologia, Nova Era, peregrinação, corporeidade

Abstract: This research is an ethnography about the experience of walking with the Associação dos Amigos do Caminho de Santiago do Rio Grande do Sul (ACASARGS). We seek here to understand how the practice of walkers can have overlapping meanings as concerns ecological and religious habits. For that end, the paper focuses on the ethnographic narrative of the motivations, interests and experiences of the walkers, seeking to understand the multiple meanings assigned to walking, which can be different and even contradictory. The theoretical and

\footnotetext{
${ }^{1}$ Mestrando em Antropologia Social pelo Programa de Pós-Graduação em Antropologia Social da Universidade Federal do Rio Grande do Sul - UFRGS. E-mail: rodrigo.toniol@ gmail.com

2 Professor do Programa de Pós-Graduação em Antropologia Social da Universidade Federal do Rio Grande do Sul - UFRGS. E-mail: casteil@uol.com.br
}

Debates do NER, Porto Alegre, ano iI, N. I7, P. 97-II9, JAn./Jun. 2010 